\title{
Wioletta Kilar
}

Zakład Przedsiębiorczości i Gospodarki Przestrzennej

Instytut Geografii

Uniwersytet Pedagogiczny im. KEN w Krakowie

\section{Rola korporacji Apple w ksztaltowaniu spoleczeństwa informacyjnego}

Problematyka społeczeństwa informacyjnego pojawiła się w połowie lat 60 . XX w. w Japonii, w wyniku szybkiego rozwoju mikroelektroniki, która wymusiła rozwój techniki cyfrowej. Pojęcie „społeczeństwo informacyjne”, rozumiane jako „społeczeństwo komunikujące się poprzez komputer", zostało po raz pierwszy wprowadzone w 1963 r. w artykule Tadao Umeesao na temat ewolucyjnej teorii społeczeństwa opartego na informacji. Pojęciem tym posługiwał się również Yonei Masuda w pracy - opublikowanej w latach 80. XX w. - na temat przemian społecznych związanych z rozwojem sektora informacji i telekomunikacji (Nowak 2005). Do Europy pojęcie „społeczeństwo informacyjne” dotarło w 1978 r. za pośrednictwem dwóch ekspertów francuskich, Simona Nory i Alaina Minca, w jednym z raportów dla prezydenta Francji. W latach 80. XX w. przyjęło się powszechnie także w Stanach Zjednoczonych. Współcześnie kluczowe dla tego pojęcia jest powiązanie komputerów ze środkami łączności, zwiększające produktywność pracy intelektualnej i kontrolowanej przez nią produkcji i dystrybucji towarów.

W niniejszych rozważaniach przyjmujemy za T. Goban-Klasem i P. Sienkiewiczem (1999, s. 53), że „społeczeństwo informacyjne to społeczeństwo, które nie tylko posiada rozwinięte środki przetwarzania informacji i komunikowania, lecz przetwarzanie informacji jest podstawą tworzenia dochodu narodowego i dostarcza źródła utrzymania większości społeczeństwa".

$\mathrm{Na}$ znaczenie nowych technologii wskazuje również raport Klubu Rzymskiego pt. Mikroelektronika a społeczeństwo, podejmujący wpływ nowych technologii na działalność człowieka.

Proces rozwoju społeczeństwa informacyjnego w podstawowym stopniu stymulują firmy informatyczne. W rozwoju społeczeństwa informacyjnego niezwykle istotny jest rozwój sektora informatyki, a ogromny wpływ na ten proces wywierają światowe korporacje informatyczne. W zależności od ich potencjału i spełnianych funkcji oddziałują one na układy przestrzenne różnej skali. Szczególne znaczenie w tym względzie mają korporacje ponadnarodowe o dużym potencjale ekonomicznym, jak Apple, IBM czy Microsoft. W wyniku wprowadzania na rynek określonych produktów ogarniają one coraz większe obszary, zmierzając do opanowania rynku światowego. Oferowany produkt, np. oprogramowanie czy możliwość uzyskiwania bądź przekazywania informacji, ujednolicają przestrzeń światową, nasilają procesy globalizacji i wpływają na kształtowanie społeczeństwa informacyjnego.

W świetle przedstawionych przesłanek, w niniejszych rozważaniach podjęta zostanie analiza procesu kształtowania się ponadnarodowej korporacji Apple - w celu określenia roli, jaką w kształtowaniu firmy odegrała pasja ludzi, którzy - mimo różnych przeszkód - w stosunkowo krótkim czasie stworzyli korporację o znaczeniu globalnym. 
Zasadniczą rolę w powstaniu Apple odegrały dwie osoby: Steve Jobs i Steve Wozniak. Znajomość obydwu założycieli rozpoczęła się na długo przed stworzeniem firmy. Wozniak, jeszcze jako student pierwszego roku Uniwersytetu Kalifornijskiego w Berkeley, dzięki sąsiadowi poznał licealistę Jobsa. Wozniak i Jobs mieli podobną osobowość; obaj reprezentowali typ człowieka wyizolowanego z otoczenia i samotnika. Łączyła ich wspólna pasja.

Geneza firmy sięga 1 kwietnia 1976 r., kiedy to 21-letni Steve Jobs i 25-letni Steve Wozniak oraz Ron Wayne założyli w Cupertino spółkę, którą nazwali Apple Computer. Udziały powstałej firmy w równych częściach (po 45\%) przypadły Jobsowi i Wozniakowi. Pozostałe $10 \%$ otrzymał Wayne za pomoc w realizacji ich pierwszego celu, jakim było złożenie płyty komputerowej za 25 dolarów, a następnie sprzedanie jej za 50 dolarów. Ten pierwszy projekt jego autorzy nazwali Apple I. Trudności pojawiły się wówczas, gdy pierwszych 50 złożonych komputerów oddawano kontrahentowi. W mniemaniu twórców projektu komputer to kompletna płyta układu, a zamawiający oczekiwał także obudowy, źródła zasilania, klawiatury i monitora. Klient jednak przystał na warunki Jobsa i Wozniaka, dzięki czemu sprzedali oni swój pierwszy produkt.

Początkująca firma do końca 1976 r. sprzedała około 150 sztuk Apple I i osiągnęła dochód 100 tys. USD. Należy wspomnieć, że chociaż za pierwszy komputer na świecie uważa się maszynę liczącą skonstruowaną w 1883 r., to pierwszym komputerem produkowanym na masową skalę, dostępnym dla klientów detalicznych, zaopatrzonym w klawiaturę i monitor, był Apple I.

W firmie dokonano podziału kompetencji. Zadaniem Steve’a Jobsa było poszukiwanie inwestorów, którzy pomogliby w rozwoju firmy, oraz podpisywanie korzystnych umów. Steve Wozniak, ze względu na dużą wiedzę teoretyczną i empiryczną w zakresie elektroniki, pracował w swoim domu nad nowym komputerem Apple II, który miał być na tyle funkcjonalny, by każdy użytkownik mógł go rozbudowywać według własnego uznania. Dużym udogodnieniem miało być wprowadzenie bezpłatnego języka programowania, ładującego się automatycznie przy włączaniu komputera. Kolejną innowacją był brak wentylatora, dzięki czemu komputer pracował cicho. Aby to osiągnąć, zatrudniono jednego z najlepszych specjalistów w dziedzinie zasilaczy - Roda Holta, który stworzył lżejszy, mniejszy i chłodniejszy zasilacz. Dzięki temu zmniejszyły się rozmiary komputera, a projekt zrewolucjonizował sposób dostarczania mocy do urządzeń elektronicznych. Apple II był pierwszym na rynku komputerem, który nie był zestawem, lecz był w pełni zmontowany, miał własną obudowę, klawiaturę i można było z niego od razu korzystać. Aby produkt mógł trafić do większej liczby klientów, firma musiała stać się rozpoznawalna na rynku, co nastąpiło po akcji reklamowej w popularnych czasopismach. Było to coś nowego; wcześniej żadna firma elektroniczna nie odważyła się reklamować swoich produktów. Niestety, nowatorom barkowało środków na sfinansowanie akcji reklamowej, dlatego Steve Jobs zaczął poszukiwać inwestora.

3 stycznia 1977 r., podczas spotkania Mike'a Markkuli, Steve’a Jobsa i Steve’a Wozniaka, podpisano umowę, na mocy której firma Apple Computer stała się korporacją. Wszyscy trzej udziałowcy uzyskali równe prawa własności, w zamian za wsparcie finansowe, jakiego udzielił Markkula, wynoszące ponad 91 tys. USD oraz gwarancję na kredyt bankowy na 250 tys. USD. Na stanowisku prezesa spółki zatrudniono Mike’a Scotta, lecz władza pozostała w rękach właścicieli firmy. Dzięki inwestorowi dokonywano kolejnych udoskonaleń w konstrukcji Apple II, na które ciągle rosło zapotrzebowanie, więc firma stale się rozwijała.

W 1978 r. Apple Computer zatrudniała około 60 osób. Po kolejnych unowocześnieniach w komputerze Apple II wprowadzono na rynek Apple III, który jednak nie odniósł sukcesu, gdyż nie działał jak należy, za co odpowiedzialność ponosił m.in. Steve Jobs, który zaprojektował do niego zbyt małą obudowę. Dużo większym zainteresowaniem wciąż cieszył się Apple II, 
zakupiony m.in. przez wiele szkół w Stanach Zjednoczonych, w których na poziomie liceum wprowadzono naukę programowania, przygotowującą uczniów do obsługi komputera. Apple II zyskał ogromny rynek edukacyjny i stał się najchętniej kupowanym komputerem przez uczniów. W tym samym roku Apple wprowadził program do edycji tekstów AppleWriter, a na początku 1979 r. zaprezentował pierwszy z powszechnie dziś znanych komputerowych arkuszy kalkulacyjnych o nazwie VisiCalc. Była to pierwsza aplikacja, dla której klienci kupowali cały komputer. VisiCalc wprowadził Apple II do firm, rewolucjonizując obliczenia. W komputerach Apple II istniała możliwość rozszerzania funkcjonalności, miały napęd dysków i można było na nich instalować oprogramowanie, stał się on zatem niezbędną maszyną biznesową. W kolejnym roku firma podwoiła sprzedaż, stając się niedoścignionym liderem w swojej branży.

W 1980 r. Apple Computer zatrudniał 200 pracowników. Powstały fabryki w Teksasie i Kalifornii oraz w Irlandii i Singapurze. Zatrudnienie ciągle wzrastało. Firma rozwinęła się tak bardzo, że jej struktura stała się niewydolna, dlatego ustalono nową, złożoną z trzech jednostek administracyjnych:

- Wydziału Akcesoriów, zajmującego sie drukarkami, dodatkowymi płytami układów oraz nowym napędem dyskietek, nad którym trwały prace;

- jednostki „Systemy Komputera Osobistego”, która zarządzała produktami linii Apple II i Apple III;

- jednostki „Profesjonalne Systemy Biurowe”, która miała się zajmować nowym projektem komputera o nazwie Lisa, konstruowanym przez najlepszych inżynierów w Apple.

Mimo że komputer Lisa był pomysłem Steve'a Jobsa, to zgodnie z nowym planem kierownictwo tego wydziału otrzymał dotychczasowy szef oprogramowania. Jobs został odsunięty od wszelkich działań operacyjnych, a przyznano mu stanowisko przewodniczącego zarządu, co było dużym ciosem dla współzałożyciela firmy. W grudniu 1980 r. ogłoszono publiczną sprzedaż akcji Apple Computer. Osiągnięto największy wówczas sukces w historii publicznej sprzedaży akcji: 4,6 mln akcji zostało sprzedanych w ciągu godziny.

W ciągu pięciu lat od powstania Apple Computer trafiła na listę największych firm amerykańskich Fortune 500, a Steve Jobs stał się jednym z najbogatszych ludzi w kraju - jego majątek wynosił ponad 217 mln USD. W tym czasie Jobs zwrócił uwagę na stworzony przez jeden $\mathrm{z}$ zespołów Apple eksperymentalny komputer, mały, niedrogi, przeznaczony dla masowego odbiorcy, który szef zespołu Jef Raskin nazwał „Macintosh”. Zmierzano do stworzenia urządzenia samodzielnego, prostego w użytkowaniu i łatwego do przenoszenia, które kosztowałoby około 1000 USD. Steve Jobs zaangażował się w ten projekt, inwestując weń pieniądze zarobione na sprzedaży akcji. Równocześnie trwały prace nad projektem komputera Lisa. Ponieważ wizje Steve'a Jobsa i Jefa Raskina na komputer Macintosh znacznie się różniły i nie mogli oni w tej sprawie dojść do porozumienia, Raskin odszedł z firmy, a Jobs został nowym szefem projektu. Ostatecznie w styczniu 1983 r. wprowadzono na rynek komputer Lisa, który - mimo że był oparty na najnowszych rozwiązaniach technologicznych i był zaopatrzony w mysz - nie zyskał zbyt dużego zainteresowania wśród klientów z powodu bardzo wysokiej ceny - koszty produkcji 1 egzemplarza wyniosły aż 10 tys. USD.

Konstruowany w tym samym czasie komputer Macintosh wprowadzono w 1984 r., poprzedzając to wydarzenie szeroką akcją reklamową. W ciągu pierwszych 100 dni sprzedano 70 tys. sztuk Macintosha. Niestety, ze względu na dość ubogie oprogramowanie (w porównaniu np. z komputerami IBM) zainstalowane w tym komputerze, na które składały się jedynie programy: MacWrite, MacPaint i MacWord, po pierwszej fali zainteresowania sprzedaż szybko spadła. Po pewnym czasie podjęto więc decyzję o zamknięciu kilku obiektów produk- 
cyjnych. Sytuacja finansowa Apple zaczęła się drastycznie pogarszać. Na wiosnę 1984 r. ostatecznie zamknięto wydział zajmujący się projektem komputera Lisa, który był nierentowny, i oficjalnie zaprzestano jego produkcji. Apple Computer po raz pierwszy zanotował straty, a 200 tys. maszyn Apple II, na które nie znaleziono klientów, trzeba było zlikwidować. W pierwszej połowie marca 1985 r. przychody ze sprzedaży Macintosha wynosiły jedynie 10\% prognozowanej wielkości. Podjęto działania zmierzające do ratowania spółki: odwołano planowany projekt Macintosh XL na rzecz mniej ambitnego Maca II, Steve Jobs stracił stanowisko szefa zespołu Macintosh, a władza został skoncentrowana w rękach prezesa firmy, Johna Sculleya. Za zgodą zarządu w ciągu miesiąca przeprowadzono reorganizację i po raz kolejny pozbawiono Jobsa wszelkich funkcji operacyjnych, proponując mu stanowisko „wizjonera produktu”. Na nowym stanowisku Jobs zajmował się głównie prowadzeniem kampanii promocyjnej na rzecz Macintosha Office. Jednakże nie spełniało to jego oczekiwań, dlatego do 1986 r. sprzedał swoje akcje, pozostawiając tylko jeden udział, by nadal otrzymywać sprawozdania roczne firmy, i ostatecznie opuścił Apple.

Niedługo później założył kolejną firmę informatyczną NeXT i kupił od George’a Lucasa studio Pixar.

W ciągu następnych kilku lat ulepszano komputer Macintosh, proponując jego kolejne wersje (Mac IIfx, Classic, LC, IIsi) i trwały prace nad nowym urządzeniem, które wprowadzono na rynek w 1991 r. Była to linia pierwszej generacji laptopów firmy Apple o nazwie PowerBook. Jego kolejne ulepszane wersje były produkowane przez Apple do $2006 \mathrm{r}$.

W latach 1993-1994 firma wprowadziła na rynek dwa kolejne produkty: pierwowzór późniejszych palmtopów - MessagPad Newton, obsługiwany za pomocą rysika i ekranu dotykowego, i Apple Pipin - multimedialną platformę, która miała być tanim urządzeniem pozwalającym na obsługę gier, pełniącą jednocześnie funkcję komputera sieciowego. Niestety, ani Newton, ani Pipin nie osiągnęły spodziewanego sukcesu rynkowego, głównie ze względu na wysoką cenę, a w przypadku platformy multimedialnej - również ze względu na brak oprogramowania, a także kiepskiej nazwy oraz dominacji na rynku takich systemów, jak Nintendo 64, Sega i Sony PlayStation (http://technologie.gazeta.pl/technologie/5,89426,4876139.html?i=1).

Sytuacja Apple Computer w 1995 r. była bardzo poważna; firma pozostawała coraz bardziej w tyle za konkurencją, np. korporacją IBM, która dominowała w dziedzinie osobistych komputerów biznesowych. Odbywały się liczne rozmowy dotyczące przejęcia Apple przez inne firmy $z$ branży komputerowej, lecz nie przyniosły one spodziewanego skutku. Zmieniono szefa zarządu; został nim Gil Amelio, który podjął się restrukturyzacji firmy. W krótkim czasie udało mu się poprawić sytuację finansową Apple, m.in. dzięki zwolnieniu 15\% pracowników. Firma musiała znaleźć producenta, który zaproponowałby zupełnie nowe i konkurencyjne na rynku oprogramowanie dla komputerów Apple. Spośród czterech kandydatów: Microsoftu, Sun, Be i NeXT, najlepszą ofertę zaproponował NeXT, który miał gotowy do produkcji system operacyjny NextStep. W ramach umowy między prezesem zarządu Apple, Gilem Amelio a właścicielem firmy NeXT, początkowym współwłaścicielem Apple, Stevem Jobsem, w roku 1996, dwadzieścia lat po rozpoczęciu działalności, Apple Computer, ze względu na przyszłe korzyści ekonomiczne wynikające z produkcji proponowanego oprogramowania, kupił firmę informatyczną NeXT Computer, a Steve Jobs powrócił do Apple, najpierw jako doradca prezesa zarządu, a od 1997 r. jako prezes, pracując za symbolicznego dolara, zarabiając na dywidendach firmy.

Apple zaczęła powoli odzyskiwać rynek. W 1998 r. wprowadzono pierwszy z serii komputerów iMac - pierwszy komputer firmy, w którym oprócz walorów technicznych, szczególną uwagę zwrócono na wygląd, do czego zwłaszcza Steve Jobs przywiązuje wagę 
przy kolejnych produktach firmy. Pierwszy model iMaca odniósł duży sukces rynkowy, który uratował Apple przed bankructwem.

Jobs musiał zmierzyć się ze spadkiem sprzedaży produktów Apple i postępującą dominacją komputerów z systemem Windows, zaproponował więc nowy kierunek rozwoju firmy: maszyny Apple'a, zamiast przypominać komputery z systemem Windows, miały się od nich maksymalnie różnić, aby klient znudzony Windowsem miał klarowną alternatywę. Kolejne oryginalne produkty wprowadzone przez Apple: laptop iBook, miniaturowe komputery biurkowe G4 Cube oraz odtwarzacz iPod, dały spółce potężny impuls do rozwoju (Rabij 2007). Na początku 2007 r. Apple zaprezentował telefon komórkowy iPhone i wprowadził do sprzedaży pokazany w 2006 r. Apple TV (wcześniej znany jako iTV) - przystawkę do telewizora umożliwiającą transmitowanie prosto do niego multimediów z dowolnego komputera. Szczególnie konkurencyjne było wprowadzenie udogodnienia, jakim jest strona internetowa iTunes, na której można zakupić pojedyncze utwory do odtwarzania na urządzeniach iPod, iPhone i Apple TV.

Wraz ze zmianą strategii przedsiębiorstwa, które weszło na rynki muzyczny i telefonii komórkowej, podczas konferencji Macworld 2007 Steve Jobs ogłosił zmianę nazwy firmy z Apple Computer Inc. na Apple Inc.

Proces rozwoju firmy przejawiał się we wzroście liczby pracujących, wartości rynkowej, wartości aktywów i sprzedaży. O bardzo silnej dynamice rozwoju świadczy fakt, że powstała w 1976 r. firma po dwudziestu dwóch latach, w 1998 r., zatrudniała 6658 osób (ryc. 1). W następnych 10 latach tempo wzrostu było jeszcze wyższe, czego wyrazem jest wzrost dynamiki zatrudnienia, do 21600 osób na początku 2008 r. (324\% w stosunku do 1998 r.).

Ryc. 1. Zmiany zatrudnienia w Apple w latach 1976-2008

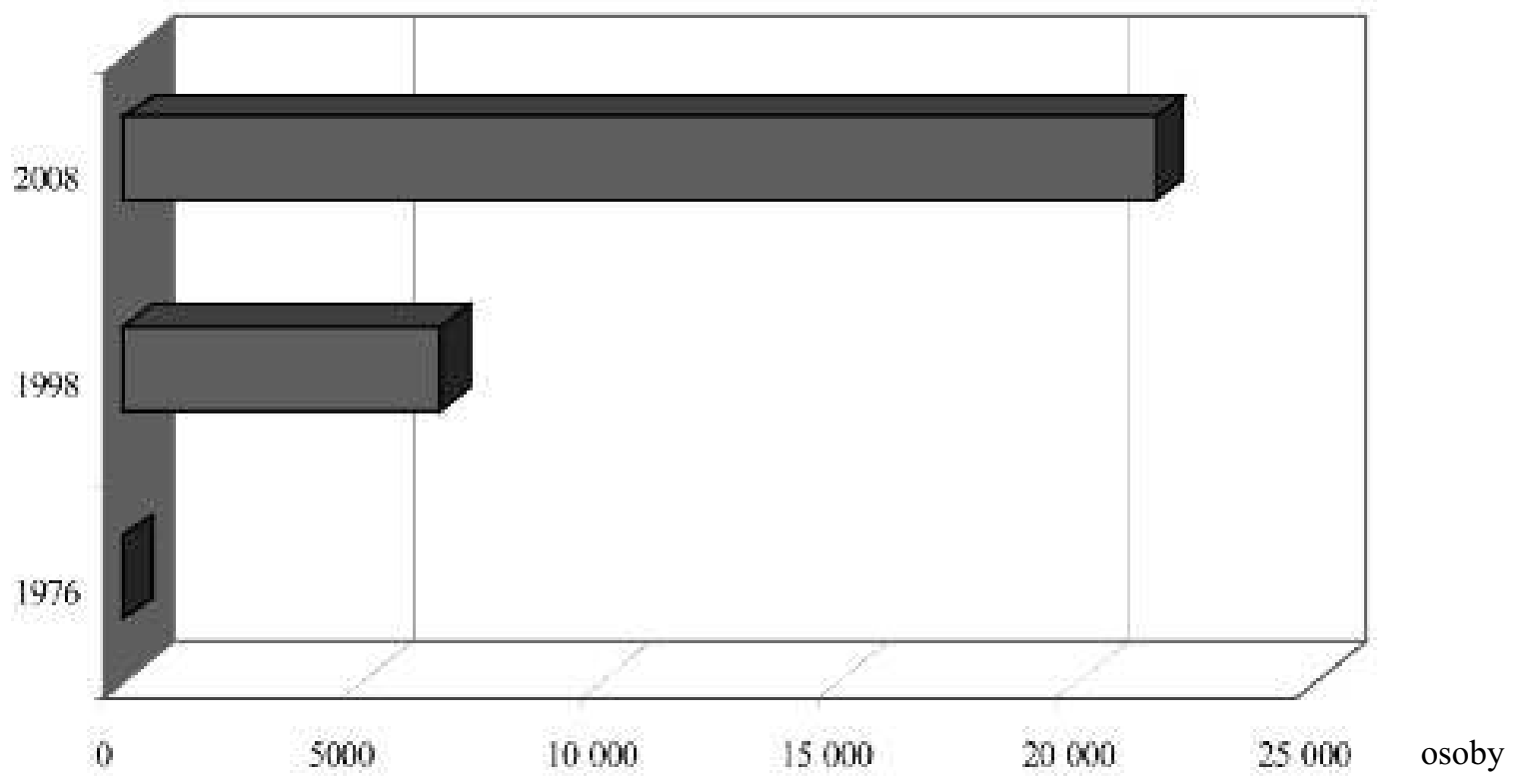

Źródło: opracowanie na podstawie http://www.apple.com/

Rozważając kwestię wartości rynkowej Apple, należy zauważyć, że w ciągu ostatnich dwunastu lat nastąpił bardzo gwałtowny jej wzrost (ryc. 2). W latach 1996-2008 wartość rynkowa firmy wzrosła z $3386 \mathrm{mln}$ USD do $109880 \mathrm{mln}$ USD, czyli nastąpił wzrost do 3245,13\%. Najistotniejsza zmiana nastąpiła w latach 2004-2005 - wzrost o 28160 mln USD, czyli o 430\%. 
Ryc. 2. Zmiany wartości rynkowej Apple w latach 1996-2008

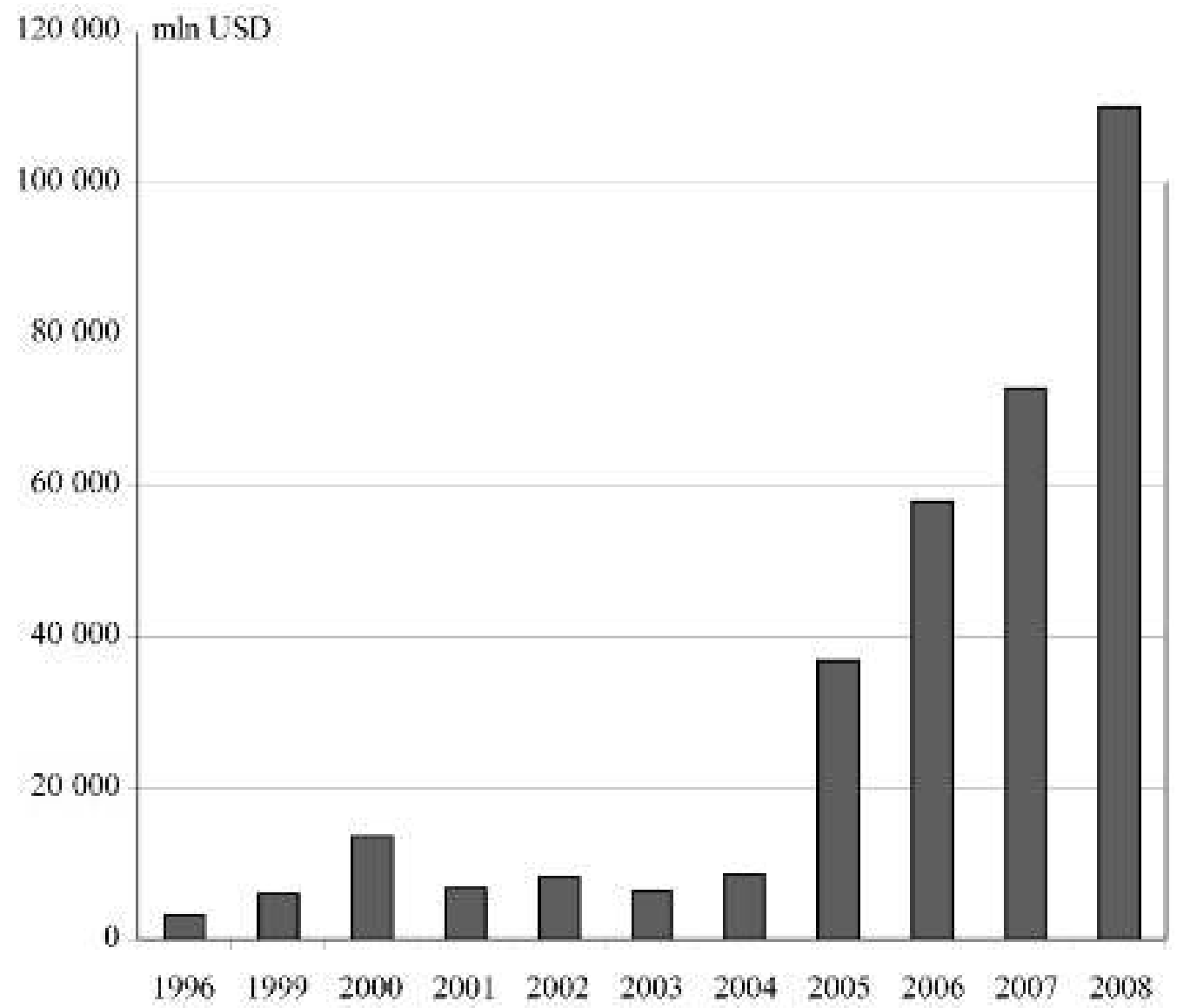

Źródło: opracowanie na podstawie rankingów „Business Week Global” i „Forbes”. ${ }^{1}$

Raporty roczne Apple wskazują na duże wahania wartości aktywów ogółem (total assets) i przychodów netto ze sprzedaży (net sales) w latach 1995-2007.

Tab. 1. Dynamika wartości aktywów i przychodów korporacji Apple w latach 1995-2007

\begin{tabular}{|c|c|c|c|c|}
\hline \multirow{2}{*}{ Lata } & \multirow{2}{*}{$\begin{array}{c}\text { Aktywa ogólem } \\
\text { (w mln USD) }\end{array}$} & $\begin{array}{c}\text { Przychody netto } \\
\text { ze sprzedaży } \\
\text { (w mln USD) }\end{array}$ & \multicolumn{2}{|c|}{ Dynamika zmian (w \%); 1995 = 100 } \\
\cline { 5 - 5 } & & 11062 & 100,0 & $\begin{array}{c}\text { aktywa ogółem } \\
\text { przychody netto } \\
\text { ze sprzedaży }\end{array}$ \\
\hline 1995 & 6231 & 9833 & 86,1 & 100,0 \\
\hline 1996 & 5364 & 7081 & 67,9 & 68,9 \\
\hline 1997 & 4233 & 5941 & 68,8 & 53,7 \\
\hline 1998 & 4289 & 6134 & 82,8 & 55,5 \\
\hline 1999 & 5161 & 7983 & 109,2 & 72,2 \\
\hline 2000 & 6803 & 5363 & 96,6 & 58,5 \\
\hline 2001 & 6021 & 5742 & 101,1 & 56,1 \\
\hline 2002 & 6298 & 6207 & 109,4 & 74,8 \\
\hline 2003 & 6815 & 8279 & 129,2 & 125,9 \\
\hline 2004 & 8050 & 13931 & 185,4 & 217,0 \\
\hline 2005 & 11551 & 19315 & 276,1 & \\
\hline 2006 & 17205 & 24006 & 406,8 & \\
\hline 2007 & 25347 & &
\end{tabular}

Źródło: opracowanie na podstawie raportów rocznych Apple za lata 1999-2007.

${ }^{1}$ Dane za lata 1996-2003 podchodzą z rankingów „The Business Week Global 1000”, a za lata 2004 -2008 - z rankingów „The Forbes”, 2000. 
Wartość aktywów wahała się w tym okresie od 4233 mln USD do 25347 mln USD (ryc. 3). W latach 1995-1999 wartość aktywów wahała się od 4233 mln USD do 5364 mln USD i była niższa niż w 1995 r., a od 2000 r. następował systematyczny wzrost ich wartości. Ostatecznie wartość aktywów wzrosła z $6231 \mathrm{mln}$ USD w 1995 roku do $25347 \mathrm{mln}$ USD w 2007 r. (do 406,8\%).

Podobne tendencje występują również w wartości sprzedaży. Wahała się ona w latach 1995-2007 od $5363 \mathrm{mln}$ USD do $24006 \mathrm{mln}$ USD, czyli nastąpił wzrost wartości sprzedaży do $217,0 \%$. W latach 1995-2001 wartość sprzedaży wahała się od 88,9\% do 48,5\% w stosunku do 1995 r., a od 2001 r. następował jej systematyczny wzrost.

Ryc. 3. Zmiany wartości aktywów i wartości sprzedaży firmy Apple w latach 1995-2007

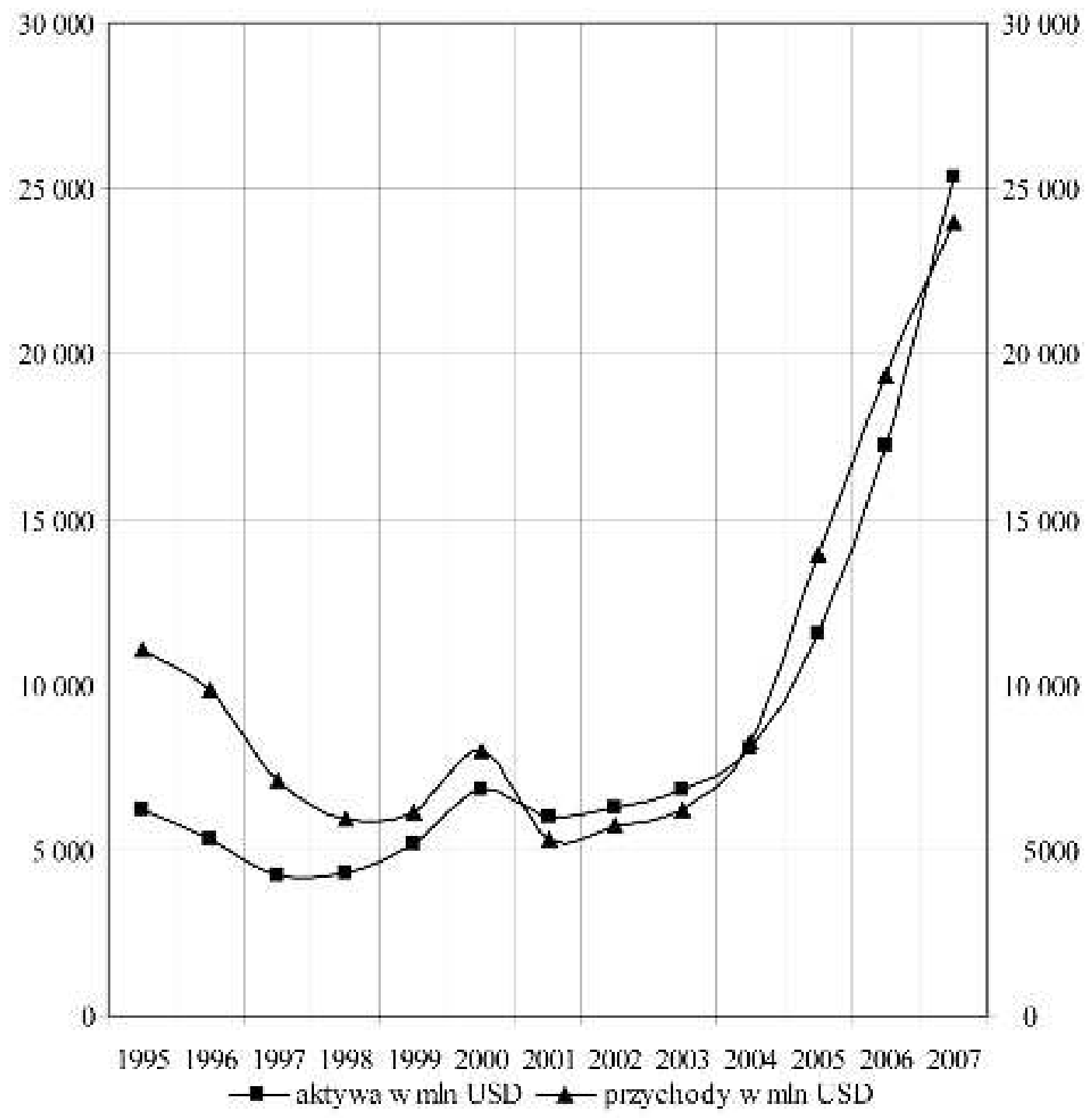

Źródło: opracowanie na podstawie raportów rocznych Apple za lata 1999-2007.

Równocześnie następowało coraz intensywniejsze opanowywanie rynku. Zasięgiem oddziaływania Apple obejmuje większość państw, poprzez sieć sklepów internetowych Apple Store funkcjonujących w 25 krajach (Australia, Francja, Belgia, Finlandia, Nowa Zelandia, Hongkong, Norwegia, Szwecja, Irlandia, Austria, Szwajcaria, Wielka Brytania, Stany Zjednoczone, Hiszpania, Holandia, Tajwan, Kanada, Włochy, Portugalia, Dania, Luksemburg, Singapur, Niemcy, Meksyk i Korea Południowa) (ryc. 4). 
Ryc. 4. Sieć sklepów Apple Store na świecie w 2008 r.

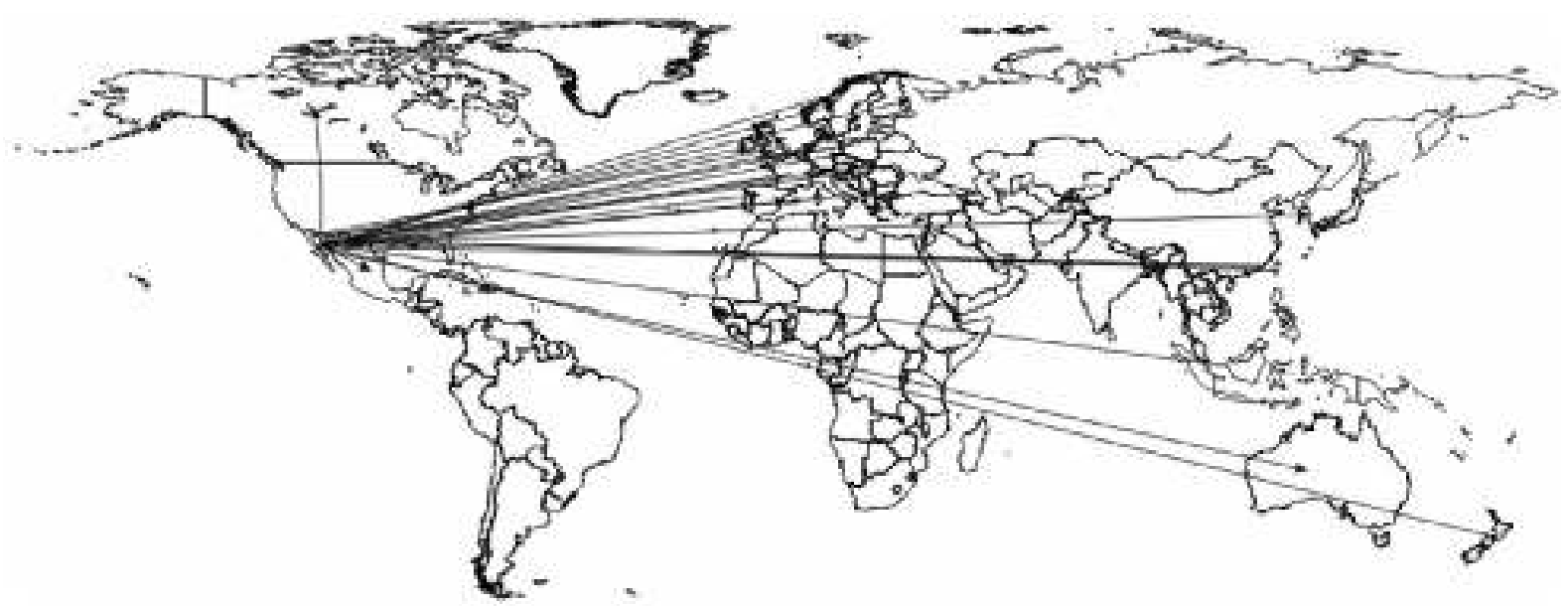

Źródło: opracowanie na podstawie http://www.apple.com/

W pozostałych krajach firma rozprowadza swoje produkty poprzez salony firmowe iSpot oraz firmy dystrybucyjne, np. Orange.

Aktualnie Apple jest znaczącą korporacją wśród światowych firm informatycznych. W rankingu 100 największych firm informatycznych ${ }^{1} \mathrm{w} 2007$ r. zajmowała 15 . pozycję pod względem wartości przychodów, wynoszących 28,7 mld USD.

Rola Apple w społeczeństwie przejawia się również poprzez rozpoznawalność korporacji na rynku. W rankingu Superbrands 2008, przeprowadzanym w ponad 80 krajach, który prezentuje najsilniejsze marki na rynkach lokalnych w edycji polskiej, marka Apple znalazła się na trzecim miejscu, wyprzedzona została jedynie przez Coca-Colę i Microsoft.

O znaczeniu korporacji Apple świadczy również wysoka, 24. pozycja w corocznym rankingu 100 najcenniejszych marek na świecie ${ }^{2}$. Wartość tej marki ocenia się na 13,7 mld USD. Szczególnie istotne jest to, że w stosunku do 2007 r. jej wartość w 2008 r. wzrosła o 24\%. Na wspomnianej liście większy wzrost wartości marki zanotowała jedynie korporacja Google (43\% w stosunku do roku 2007).

Wydaje się, że przedstawiony proces kształtowania się firmy, która rozwinęła się bardzo silnie przez 32 lata, może być dobrym przykładem korporacji, która poprzez wprowadzanie coraz nowocześniejszych, funkcjonalnych urządzeń w znaczący sposób wpływa na kształtowanie się społeczeństwa informacyjnego. W rozwoju Apple szczególną rolę odegrał jej współzałożyciel, Steve Jobs. Może on być dobrym wzorcem do naśladowania, gdyż pokonuje wszelkie trudności, dążąc do rozwijania swoich pasji badawczych i realizacji założonych celów.

\section{Literatura}

1. Friedmann T. L., 2006, Świat jest płaski. Krótka historia XXI wieku, Dom Wydawniczy REBIS, Poznań.

2. Goban-Klas T., Sienkiewicz P., 1999, Spoteczeństwo informacyjne: szanse, zagrożenia, wyzwania, Wydawnictwo Fundacji Postępu Telekomunikacji, Kraków.

3. Horodecki J., 2008, Komputer mówi o firmie, „Manager magazin”, edycja polska, 3 (38), marzec 2008, s. 44 i 45.

4. Krasoń M., 2008, Biżuteria dużego zasięgu, „Manager magazin”, edycja polska, 7 (42), lipiec 2008, s. 92-94.

${ }^{1}$ The Info Tech 2007, publikowanym przez „Business Week”.

${ }^{2}$ Best Global Brands 2008. 
5. Mikroelektronika i spoleczeństwo: na dobre czy na złe? Raport dla Klubu Rzymskiego, 1987, Książka i Wiedza, Warszawa.

6. Mikuła B., 2006, Organizacje oparte na wiedzy, „Zeszyty Naukowe. Seria specjalna: Monografie”, nr 173, Wydawnictwo Akademii Ekonomicznej w Krakowie, Kraków.

7. Nowak J.S., 2005, Społeczeństwo informacyjne-geneza i definicje [w:] Społeczeństwo informacyjne 2005, G. Bliźniuk, J.S. Nowak (red.), Wydawnictwo Polskiego Towarzystwa Informatycznego, Oddział Górnośląski, Katowice.

8. Rabij M., 2007, Papież Doliny Krzemowej, „Newsweek”, 28/07, 15.07.2007, s. 56-59.

9. Rachwał T., 2004, Podstawy przedsiębiorczości. Stownik dla liceum ogólnokształcacego, liceum profilowanego i technikum, Wydawnictwo Nowa Era, Warszawa.

10. Raport roczny Apple (Apple Computer) za lata 1999-2007.

11. Upsetting the Apple Cart [w:] "Buisness English Magazine", 7/2008 sierpień/wrzesień, s. 24 i 25.

12. Young J., Simon W. L., 2006, iCon. Steve Jobs, najbardziej niezwykly akt II w historii biznesu, Wydawnictwo Studio EMKA.

13. http://technologie.gazeta.pl/technologie/5,89426,4876139.html?i=1

14. http://www.apple.com

15. http://news.cnet.com/2009-1001-259424.html

16. http://www.applefritter.com/apple1

17. http://apple2history.org/

18. http://www.apple-history.com/

19. http://www.theapplemuseum.com/

\section{Role of Apple Corporation in Forming Information Society}

This article provides the study of the process of shaping supranational Apple Corporation. An attempt was made to define the importance of the role in the development of the corporation played by Stave Jobs, its co-founder, as well as the role of Apple Corporation in forming the information society.

The process of developing the company has been marked by an increase the number of employees, the market value, the assets value, and the sales, etc. Simultaneously, the market dominance was established more and more intensively. The company operates in most countries of the world. 